\title{
THE ROLE OF THE ASEAN INTERGOVERNMENTAL COMMISSION OF HUMAN RIGHTS IN GIVING PROTECTION TO THE ETHICS ROHINGYA OF THE SPIRIT IN SOUTHEAST ASIA
}

\author{
Endah Rantau Itasari \\ Universitas Tanjungpura Pontianak \\ Email : endah.rantau.itasari@hukum.untan.ac.id
}

\begin{abstract}
The purpose of this study is to provide legal protection to the ethnic Rohingya, with the ASEAN Charter and the establishment of the ASEAN Intergovernmental Commission of Human Rights will strengthen the instruments in protecting human rights in ASEAN. Philosophically with the establishment of the ASEAN Intergovernmental Commission of Human Rights, member countries would prefer a regional settlement to an international one. Regional settlements were chosen because the rules are adapted to regional conditions. This ASEAN Intergovernmental Commission of Human Rights needs a strong foundation and position to be able to give a reprimand. Rohingya is one example of ASEAN's failure to guarantee human rights in the region. If this conflict cannot be resolved, of course, it is possible that future human rights violations will occur again. This research is a normative juridical study, the ASEAN Intergovernmental Commission of Human Rights is obliged to provide protection to ethnic Rohingya because the violation occurred in the Southeast Asia region and it is time for ASEAN member countries to give strict sanctions to Myamar due to the behavior given to the Rohingya ethnicity. The principle of non-intervention contained in the ASEAN Way will always be a barrier for ASEAN member countries in providing protection to ethnic Rohingya in Myanmar, but ASEAN member countries must continue to persuade Myanmar to respect every human right without exception. and ask for help from the international community to pressure Myanmar to stop persecuting the Rohingya.
\end{abstract}

\section{Keywords: Human Rights; Rohingya; Legal Protection}

\section{INTRODUCTION}

Human Rights is affirmed by Daniel S. Lev to be equally attached to all humans, because humanity has a single biological species: the most basic unity, so that based on this similarity the differences will be meaningless. Thus, the concept of human rights is universal and does not recognize meanings or interpretations which are only characterized by local specificities. Many governments do not like this, because the concept that is universal will limit everything that is done by the government and instead protects citizens against state power. ${ }^{1}$

\footnotetext{
${ }^{1}$ Arianta, K., Mangku, D. G. S., \& Yuliartini, N. P. R. (2020). Perlindungan Hukum Bagi Kaum Etnis Rohingya Dalam Perspektif Hak Asasi Manusia Internasional. Jurnal Komunitas Yustisia, 1(1), p. 93-111.
} 
Human rights in Yozo Yokota's view means that these rights are for every human being, regardless of race, nationality, religion or culture. If discussing only European, African and Asian human rights, however, it can no longer talk about human rights in general. Because the concept of human rights is universal, the contents of the concept should also be universally specified. One region or one culture should not monopolize the power to determine human rights standards that can be applied universally. Thus, Asia's view needs to be reflected in the preparation of human rights that can be applied throughout the world, rather than trying to formulate human rights conventions specifically for the Asian region. ${ }^{2}$

The explanation above is a general view of human rights. Since the release of Myanmar's opposition leader, Aung San Suu Kyi, the democratic process of Myanmar has begun to find a bright spot and is good news for ASEAN especially in the Southeast Asia region and has made this ASEAN member country the main topic of discussion in the world. Hopes are beginning to emerge to uphold human rights in the country, as a developing country Myanmar has attracted a lot of international attention, starting the Government of Myanmar free of charge 42 child soldiers ${ }^{3}$, where the Myanmar armed forces released at least 42 children who had been they are recruited to become soldiers or to do various other military work. ${ }^{4}$

Since the enactment of the ASEAN Charter and it has been ratified by all ASEAN members, Southeast Asia now has a Human Rights Body which has been included in the ASEAN Charter. The establishment of the ASEAN Human Rights Body shows progress, but on the other hand there are concerns that this institution will not be effective. The establishment of the ASEAN Human Rights Body aims to promote and protect human rights and help enrich and improve human rights standards in ASEAN in accordance with the regional context and as a channel for constructive cooperation on human rights issues among ASEAN countries. It is hoped that the ASEAN Human Right Body will be able to provide protection for Rohingya ethnicities whose lives are being threatened.

They were released as part of an agreement between the government and the military of Myanmar with the United Nations (UN), besides that the international community has already revoked economic sanctions against Myanmar which has made many investors interested in investing their capital there. Coca-Cola, for example, returned to Myanmar after more than six decades of leaving the country. Still in our minds The

\footnotetext{
${ }^{2}$ Mahmood, S. S., Wroe, E., Fuller, A., \& Leaning, J. (2017). The Rohingya people of Myanmar: health, human rights, and identity. The Lancet, 389(10081), p. 1841-1850.

${ }^{3}$ Beyrer, C., \& Kamarulzaman, A. 2017. Ethnic cleansing in Myanmar: the Rohingya crisis and human rights. The Lancet, 390(10102), p. 1570-1573.

${ }^{4}$ Wringe, Colin, 2006, Moral Education: Beyond the Teaching Rights and Wrong, Springer, p.34
} 
political issue in the Southeast Asian region which until now has become the center of attention of the world and ASEAN in particular is the issue of Myanmar. ${ }^{5}$

This issue arose about sixteen years ago when the military junta in Rangon cracked the pro-democracy movement driven by Aung San Suu Kyi. The junta action caused a strong reaction from the international community. At the Southeast Asian level, this issue is considered by ASEAN as an issue that will not only affect ASEAN's long-term cohesiveness and international image, but also ASEAN's relations with other countries and international institutions outside ASEAN. The pattern of ASEAN relations with state actors outside the region to a certain extent, is determined by how seriously ASEAN is willing to address the problem of democracy and the enforcement of human rights in Myanmar. ${ }^{6}$

The Myanmar issue has raised differences in views and attitudes among ASEAN member countries regarding ways to handle the Myanmar case as well as about the implications of the case for future ASEAN cooperation. As if ASEAN was never free from Myanmar's problems ${ }^{7}$, especially when ASEAN talked about how to build a more democratic Southeast Asia region. The issue of Myanmar is almost never absent from the agenda of the internal meetings of the ASEAN Foreign Ministers and between ASEAN and its dialogue partners, because the United States' insistence on the issue of Myanmar was even nearly discussed at the UN forum, when the United States saw the brighter prospects of democratization in Myanmar. ${ }^{8}$

For the first time in the 38-year history of the formation of ASEAN, this regional organization in the Southeast Asia region has openly criticized one of its members, Myanmar regarding the poor record of Human Rights (HAM). If so far ASEAN has always been strong in the implementation of its non-intervention principles, now ASEAN leaders at the 11th ASEAN Summit in Kuala Lumpur, December 2005 began to dare to voice direct criticism of Myanmar that "its right recorded an embarrassment and demanded the release of opposition leader, Aung San Suu Kyi, and of other political prisoners. $^{9}$

The above is a small part of the progress that is being experienced by Myanmar in the international arena, but Myanmar still leaves a very important and fundamental

\footnotetext{
${ }^{5}$ Haar, R. J., Wang, K., Venters, H., Salonen, S., Patel, R., Nelson, T., ... \& Parmar, P. K. 2019. Documentation of human rights abuses among Rohingya refugees from Myanmar. Conflict and health, 13(1), p. 42.

${ }^{6}$ Bandoro, Bantarto, 2003, Mahatir's Myanmar Policy Not Just Empty Rhetoric, The Jakarta Post, tanggal 29 Juli 2003

${ }_{7}$ Bandoro, Bantarto, 2006, Mynamar dan Negara-negara Ekstra Regional : Perspektif "Mesin Presto", Analisis CSIS Vol. 35 Nomor 2, Jakarta, p. 141-142

${ }^{8}$ Brooten, L. (2015). Blind spots in human rights coverage: Framing violence against the Rohingya in Myanmar/Burma. Popular Communication, 13(2), p. 132-144.

${ }_{9}^{9}$ Kurniawan, N. 2018. Kasus Rohingya dan Tanggung Jawab Negara dalam Penegakan Hak Asasi Manusia. Jurnal Konstitusi, 14(4), p. 880-905.
} 
problem that has brought Myanmar back to the same "gap" about human rights issues, which is an indication that the Myanmar government (still) is doing human rights violations of the Rohingya ethnic group. History still records that the release of Aung San Suu Kyi's Nobel Peace Prize laureate and the entry of Suu Kyi into Myanmar's parliament raised hopes for the Rohingya minority's continued oppression. They hoped that Suu Kyi would speak out against the rights of the Rohingya, a people the United Nations calls the most persecuted minority in the world. But what happened, Suu Kyi still avoided the issue. As happened when Suu Kyi spoke in Geneva, Suu Kyi looked like there was no big problem by not wanting to offend the Myanmar regime. ${ }^{10}$

The issue of the massacre of the Rohingya in Arakan Province, Myanmar, re-emerged along with the arrival of the holy month of Ramadan. In the notes of A. Safril Mubah, in the past month, 650 ethnic Rohingya were recorded dead, 1,200 residents were missing, and around 80 thousand others were displaced. Over the years Myanmar's military junta government not only denies democracy, but also violates the human rights of minorities. The United Nations (UN) and Western countries, it seems, are not at all uncomfortable with the news of the massacre of the Rohingya Muslims. In fact, the leader of the country that has the most Muslim population in the world, Indonesia, also closed its eyes. The Ministry of Foreign Affairs regards the issue as Myanmar's internal problem.

The Rohingya case is indeed not a matter of religion. They were not slaughtered because of Islam. But, against the background, the Rohingya ethnic is not recognized as one of the ethnic groups in Myanmar. For the Myanmar government, the Rohingya are considered stateless people. On that basis, the Myanmar army committed various human rights violations. Some ethnic Rohingya then fled to various countries, including Nanggroe Aceh Darussalam. Whatever the reason, the slaughter of the Rohingya ethnic group must be stopped. Regardless of whether they are Muslims or not, crimes against humanity cannot be tolerated.

ASEAN can schedule a more serious discussion of Rohingya ethnic issues. The fate and future of the ethnic minorities must be clear. Because they are in the Southeast Asian region, ASEAN must provide certainty of citizenship for the ethnic group, the Rohingya ethnic issue must be resolved. It is inappropriate for ASEAN to be led by a country which legalizes the slaughter of certain ethnic groups. In writing this article, we will discuss about the role of the ASEAN human rights body in providing protection for the Rohingya in Southeast Asia?. The type of research that I use is normative legal research, with the data collection method used is library research. The data used includes

${ }^{10}$ Lee, R. 2014. A politician, not an icon: Aung San Suu Kyi’s silence on Myanmar's Muslim Rohingya. Islam and Christian-Muslim Relations, 25(3), p. 321-333. 
primary legal material (binding materials), secondary legal material (legal material that provides an explanation of primary legal material). ${ }^{11}$ To achieve the research objectives, the approach in this study is carried out carefully through the provisions of legislation and various doctrines (opinions of legal experts) relating to the problem of provide legal protection to the Rohingya in Southeast Asia based on international human rights. The materials that have been collected are then analyzed by analytical descriptive method, so that the picture is related to the existing problems.

\section{DISCUSSION}

\section{Human Rights in the ASEAN Perspective}

Human rights are about the relationship between citizens and their countries regarding the obligation of the state to promote and secure the special basic rights of citizens as specified in these instruments. Many of these basic rights are recognized by the constitutions of countries, such as the right to life, the right of association in unions whose purpose is not detrimental to others, the right to express ideas that do not slander others, the right to embrace religious beliefs, the right to private property, the right to demand justice legally, the right to due process of law, among others. Then human rights violations occur, if the state or its officials or apparatus violate the rights of citizens involved in these violations usually are the military and police in their task of upholding security, peace and order. ${ }^{12}$

Human rights issues have increasingly become a global concern and threaten divisions between developed and developing countries as a result of the conflicting views of the North South of the 1960s to the early 1980s. There was a period in World War II and the post-war era wanted to reduce the exclusive jurisdiction of the state over its citizens on the one hand, and the internationalization of individual institutions for dealing with countries where they were citizens on the other. This protection institution has been known as human rights. The UN is a pioneer in this development, one of its main objectives is to promote human rights. ${ }^{13}$

Then there is the Universal Declaration of Human Rights in 1948, the International Covenant on Economic, Social and Cultural Rights in 1966, and the International Covenant on Civil and Political Rights in 1966. International Covenant on Racial Discrimination, Agreement on the Annihilation of a Nation and International Covenants

\footnotetext{
12 .

${ }^{11}$ Soerjono Soekanto dan Sri Mamudji, 2001, Penelitian Hukum Normatif, Raja Grafindo, Jakarta, p.

${ }^{12}$ Mahmood, S. S., Wroe, E., Fuller, A., \& Leaning, J. 2017. The Rohingya people of Myanmar: health, human rights, and identity. The Lancet, 389 (10081), p. 1841-1850.

${ }_{13}$ Shivakoti, R. 2017. ASEAN's role in the Rohingya refugee crisis. Forced Migration Review, 56, p. 75-77.
} 
on the Rights of the Child. In ASEAN there is an international agreement namely the ASEAN Charter. ${ }^{14}$ In the UN Charter, Article 1 of the Charter explains that one of the UN's objectives is "to achieve international cooperation in solving international problems characterized by economic, social, cultural, or humanitarian nature, and" in promoting and promoting respect for human rights and basic freedoms for all regardless of race, gender, language or religion " .15

And Article 55 explicitly links human rights to stability, prosperity, and peaceful and friendly relations between nations. Article 56, countries that are members of the United Nations oblige themselves to pursue noble goals, the language of Article 56 in this case is that all members pledge to take joint or individual actions in cooperation with the United Nations in order to achieve the objectives stated in Article 55 UN Charter. ${ }^{16}$

ASEAN is an international organization located in Southeast Asia, which has ten member countries and aims to create security stability in the region. All ASEAN member countries, although they have many similarities in history, culture, goals and so on, are still very different from each other. More especially about the problem being discussed, perhaps is the fact that the ruling elites have different orientations in key matters directly related to the issue of human rights.

The participation of ASEAN member countries in various international human rights instruments varies greatly. Of the 24 international human rights instruments covering the entire spectrum of human rights, the Philippines participated in 20 instruments, Indonesia, Singapore and Thailand participated in three and Malaysia in two instruments. Only Brunei is the only country that does not participate in any of the instruments, the Philippines already has an independent national human rights monitoring body, which is recognized and held on the mandate of its constitution. ${ }^{17}$

The ASEAN Charter as an international agreement was born out of a long series of negotiations. Aligning and then agreeing on the interests of the ten ASEAN member countries in a legally binding collective forum is only one of the many diplomatic efforts that must be undertaken for the birth of the ASEAN Charter. Peace, stability, progress, and shared prosperity among the regions are among the basic interests which can ultimately unite the countries of Southeast Asia in an ASEAN forum. ${ }^{18}$

ASEAN has a set of rules of the game in relations between countries in the Southeast Asia region which is often referred to as the ASEAN Way. The ASEAN Way is norms

${ }^{14}$ Beiter, Klaus Dieter, 2005, The Protection of the Right to Education by International Law, Martinus Nijhoff Publisher, p. 234

${ }^{15}$ Baehr, Peter, Pieter Van Dijk, Adnan B. Nasution, Leo Zwaak, 2001, Instrumen Internasional Pokok Hak-hak Asasi Manusia, Yayasan Obor Indonesia, Jakarta, p. 56

${ }^{16}$ Beitz, Charles, 2009, The Idea of Human Rights, Oxford University Press, p. 56

${ }_{17}$ Blokker and Schemers, 2003, International Institutional Law, Fourth Edition, Leiden, p. 134

${ }_{18}$ Eide (et.al.), Asbjorn, 1995, Economic, Social and Cultural Rights, A Textbook, Martinus Nijhoff, Dordrecht, p. 34 
inherent in institutions by emphasizing the principle of non-intervention that respects the sovereignty of other countries and uses a consultation and consensus approach in solving issues in the region rather than using confrontation / violence, the ASEAN Way's code of conduct is shown by: ) adherence to non-intervention, non-violent means and peace resolution in conflicts; (2) promote regional autonomy and collectivity; (3) rejection of multilateral military pacts; and (4) preference for socio-cultural norms based on informal consultation and consensus rather than legal-rational norms in decision making.

One of the new innovations contained in the clauses of the ASEAN Charter is related to the provisions governing the promotion and protection of human rights, especially the mandate for the establishment of the ASEAN Human Rights Body. ${ }^{19}$ In the ASEAN Charter there are clauses that provide new hope for the protection of human rights in ASEAN. These human rights issues are found in the preamble, purposes (Article 1 paragraph (7), principles (Article 2 paragraph (2) (i) and Article 14 which specifically regulates human rights. At the preamble (Preambule) of the agreed ASEAN Charter, ASEAN countries are mandated to adhere to the respect and protection of human rights and fundamental freedoms. The statement is explicitly spelled out in the objectives and principles of the establishment of ASEAN namely Article 1 paragraph (7) and Article 2 paragraph (2) (i) that ASEAN is determined to advance protect human rights in the ASEAN region. ${ }^{20}$

This principle implies that ASEAN must play a real role in maintaining the sustainability of the ASEAN region in providing promotion and protection of human rights. To support this effort, ${ }^{21}$ Article 14 of the ASEAN Charter emphasizes that in order to be consistent with the aims and principles of the ASEAN Charter relating to the promotion and protection of human rights and fundamental freedoms, ASEAN must establish an ASEAN Human Rights Body, whose tasks are in accordance with the terms of reference to be determined by a meeting of ASEAN Foreign Minister. Thus, the establishment of the ASEAN Human Rights Body is a necessity that must be carried out as a "spearhead" in realizing the goals and principles of ASEAN. ${ }^{22}$

\footnotetext{
${ }^{19}$ Seah, D. 2009. The ASEAN Charter. The International and Comparative Law Quarterly, 58(1), p. $197-212$.

${ }^{20}$ Arendshorst, J. 2009. The dilemma of non-interference: Myanmar, human rights, and the ASEAN charter. Nw. UJ Int'l Hum. Rts., 8, p. 102.

${ }^{21}$ Desierto, D. A. 2010. ASEAN's Constitutionalization of International Law: Challenges to Evolution Under the New ASEAN Charter. Colum. J. Transnat'l L., p. 49, 268.

${ }_{22}$ Mangku, D. G. S. 2011. Peluang dan tantangan ASEAN dalam penyelesaian sengketa Kuil Preah Vihear di perbatasan Kamboja dan Thailand. Pandecta: Jurnal Penelitian Ilmu Hukum (Research Law Journal), 6(2), p. 23
} 
The Role of The ASEAN Intergovernmental Commission of Human Rights In Providing Protection to The Ethics of The Spirit in Southeast Asia

The Rohingya are an ethnic group originating from Bangladesh, but have settled in the state of Rakhaing in Myanmar since the 7th century AD. Even though they have lived in Myanmar for centuries, the Myanmar government considers that the Rohingya are ethnic Bengalis and cannot be recognized as one of Myanmar's ethnicities. The loss of citizenship has prevented the Rohingya from receiving national protection. The Rohingya are experiencing various human rights violations, both in terms of citizenship and religion. It was these human rights violations that prompted the Rohingya ethnic group to leave Myanmar and seek protection in other countries, some of whom arrived in Indonesia. ${ }^{23}$

Citizenship is a human right. A person who does not have citizenship means that he does not have legal protection and cannot enjoy the rights as he should, for example cannot participate in political processes because he does not have the right to vote; not guaranteed the right to education, the right to health care, the right to work; not getting travel documents, etc.

Thus, citizenship has a very important function for everyone to be able to obtain other rights that are recognized before the law. People who do not have citizenship can be found in almost all regions of the world. In this case, the ethnicity of his Spirit was not recognized by Myanmar's government by the issuance of the Burmese Citizenship Law 1982. In Article 3 it is stated that, "Nationals such as the Kachin, Kayah, Karen, Chin, Burman, Mon, Rakhine or Shan and ethnic groups as have settled in any of the territories included within the State as their permanent home from an anterior period to 1185 BC, 1823 AD are Burmese citizens. "However, Article 4 states that, "the Council of State may determine whether any ethnic group is national or not". ${ }^{24}$

In this case, the Myanmar Council does not recognize the Rohingya ethnicity as Myanmar citizens, but considers that the Rohingya ethnic is Bangladeshi. In determining one's citizenship there are a number of principles commonly used as guidelines for a country. The principle is the principle of ius soli and ius sanguinis; and the principle of citizenship in terms of marriage, namely the principle of legal unity and the principle of equality. Ius soli and ius sanguinis are two theories of citizenship which are based on one's birth. Ius soli means guidelines based on place or region. ${ }^{25}$

\footnotetext{
${ }^{23}$ Ifdal Kasim \& Johanes da Masenus Arus (eds.), 2001, Hak Ekonomi, Sosial dan Budaya: Esai-esai Pilihan, Lembaga Studi dan Advokasi Masyarakat (Elsam), Jakarta p. 56

${ }^{24}$ Leider, J. 2018. Rohingya: The history of a Muslim identity in Myanmar. In Oxford Research Encyclopedia of Asian History., p. 56

${ }^{25}$ Haque, M. M. 2017. Rohingya ethnic muslim minority and the 1982 citizenship law in burma. Journal of Muslim Minority Affairs, 37(4), p. 454-469.
} 
Whereas ius sanguinis means guidelines based on blood or heredity. In this case the Rohingya ethnic status as ethnicity that does not have citizenship because Myanmar as their birthplace adheres to the principle of ius sanguinis (Article 5 of the Burmese Citizenship Law 1982 states that, "Every national and every person born of parents, both of whom are nationals are citizens by birth), while Bangladesh as a place where their ethnic origin adheres to the principle of ius soli (Article 2 of the Bangladesh Citizenship Act No. II of 1951 states that, "Notwithstanding anything contained in any other law, on the commencement of this Order, every person shall be deemed to be a citizen of Bangladesh, (i) who or whose father or grandfather was born in the territories now comprised in Bangladesh and who was a permanent resident of such territories on the 25th day of March, 1971 and continues to be so resident; or (ii) who was permanent resident of the territories now comprised in Bangladesh on the 25th day of March, 1971, and continues to be so resident and is not otherwise disqualified for being a citizen by or under any law for the time being in force.").

The right to citizenship is a human right to personal freedom. Under Article 15 paragraph (1) of the Universal Declaration of Human Rights 1948, everyone has the right to citizenship. Furthermore, in paragraph (2) it is stated that no one can be arbitrarily revoked of his citizenship, or denied his right to change his citizenship. The Relating to the Stateless Persons 1954 and the 1961 Convention on the Reduction of Statelessness are international legal instruments that guarantee the protection of ethnic groups that do not have citizenship and the minimum treatment that must be applied to these ethnic groups. After being criticized by a number of international human rights groups, the Burmese government said that its minority Muslim Rohinya had the right to register for citizenship.

On November 18, 2012 at the ASEAN Submit or ASEAN summit in Cambodia, the heads of ASEAN member countries signed the ASEAN Human Rights Declaration. The declaration is expected to be able to equalize perceptions and improve protection of human rights in the area of 600 million inhabitants. It is also expected to become a standard of human rights in ASEAN member countries. ASEAN member countries, namely Brunei Darussalam, Cambodia, Indonesia, Malaysia, Myanmar, Laos, Thailand, Vietnam, the Philippines, and Singapore, have different human rights laws, systems and conditions. With the declaration, 10 member countries inevitably must submit to the ASEAN Declaration of Human Rights. ${ }^{26}$

The ASEAN Declaration of Human Rights is one of the mandates of the ASEAN Intergovernmental Commission on $\mathrm{H}$ uman Rights (AICHR) or the ASEAN

${ }^{26}$ Singh, B. 2014. ASEAN, Myanmar and the Rohingya issue. Himalayan and Central Asian Studies, $18(1 / 2)$, p. 5 . 
Intergovernmental Commission on Human Rights. The AICHR was established on October 23, 2009 based on Article 14 of the ASEAN Charter, which mandated the establishment of a human rights commission in ASEAN. ${ }^{27}$ In addition to the AICHR, ASEAN also has the Commission for the Protection and Promotion of the Rights of Women and Children (ASEAN Commission for the Promotion and Protection of the Rights of Women and Children - ACWC) which was established on 7 April 2010 at the 16th ASEAN Summit. This commission is one of the regional mechanisms that is more focused on the promotion and protection of the rights of women and children. ${ }^{28}$

For this reason, a real and competent forum for cooperation in the field of human rights is needed in the Southeast Asia region. This was shown by the formation of the idea to form a human rights commission at the ASEAN regional level, which was named AICHR. The birth of the ASEAN Interngovernmental Commission on Human Rights (AICHR) can serve as a response to human rights cooperation by state actors. As the main supporter and make a significant contribution to the enforcement of human rights, especially in Southeast Asia.

AICHR is a consultative intergovermental body and is an integral part of the ASEAN organizational structure. AICHR is the main human rights institution at the ASEAN level which is responsible for the promotion and protection of human rights in ASEAN.8 AICHR will cooperate with other ASEAN bodies related to human rights in order to coordinate and synergize in the field of human rights. Each ASEAN member country appoints a representative who is considered competent in the field of human rights. In its development, human rights cooperation in ASEAN has been slow. AICHR can be said to be late in terms of sparking human rights cooperation. The effectiveness of a human rights institution in ASEAN through state actors should be questioned. This is due to the principles in the ASEAN Charter contained in article 2 (e) concerning "Not to interfere in the domestic affairs of ASEAN member countries". In progress to achieve the fulfillment of human rights in ASEAN, often encounter various obstacles. The principle of non-intervention which is contained in the consensus contained in the ASEAN Charter, is often used as a shield by member countries to remain adamant in defending the sovereignty of each member state, including the issue of human rights itself.

The role of AICHR in encouraging the promotion and protection of human rights in the ASEAN Region is a form of response given by AICHR to human rights violations. The role played by AICHR is carried out through several programs and activities in the

\footnotetext{
${ }^{27}$ Mahmood, S. S., Wroe, E., Fuller, A., \& Leaning, J. 2017. The Rohingya people of Myanmar: health, human rights, and identity. The Lancet, 389(10081), p. 1841-1850.

${ }^{28}$ Lee, R. 2014. A politician, not an icon: Aung San Suu Kyi's silence on Myanmar's Muslim Rohingya. Islam and Christian-Muslim Relations, 25(3), p. 321-333
} 
organization. These activities and programs consist of the establishment of the ASEAN Declaration on Human Rights and legal instruments related to human rights, increasing public awareness of human rights, encouraging capacity building of ASEAN member countries to implement human rights obligations effectively, strengthening human rights norms in ASEAN, encouraging the participation of ASEAN member countries in various international human rights forums, encouraging dialogue and consultation and cooperation among ASEAN countries involving national, international institutions and other stakeholders, as well as providing advisory services and technical assistance to ASEAN sectoral bodies.

Like the AICHR, the ACWC is also an intergovernmental body and an inseparable part of the ASEAN Organizational Structure and a consultative body. Philosophically, with the establishment of the ASEAN Human Rights Body, member countries would prefer a regional settlement to an international one. Regional settlements were chosen because the rules are adapted to regional conditions. This ASEAN Human Rights Body needs a strong foundation and position to be able to give a reprimand. The question arises whether the scope of authority and duties is capable resolving cases of human rights violations committed by ASEAN member countries?, while the basic principle in the ASEAN Charter is to respect the principles of territorial integrity, sovereignty, nonintervention and national identity of ASEAN members?. ${ }^{29}$

The question above is very interesting for us to examine together, it cannot be denied anymore that this is what makes it a dilemma for ASEAN members in solving a problem especially the human rights issues that afflict ethnic Rohinya. Any form of violence perpetrated by the Government of Myanmar against ethnic groups which according to the UN is the most persecuted ethnic minority in the world cannot be justified by the international community and by ASEAN, in this case Myanmar is still a permanent member of ASEAN and has agreed to jointly uphold human rights people in Southeast Asia are proven by the ratification of the Human Rights Body in ASEAN. It is hoped that all parties with the establishment of the ASEAN Human Rights Body can be a solution and can solve the problems that are being faced by the ethnic Rohingnya, by urging the Myanmar government to strictly implement the principles contained in it and prioritize humanitarian principles to deal with ethnic issues This Rohingya.

The ASEAN Human Rights Declaration, which was formed as a continuation of the ASEAN Charter which applies in general, still has shortcomings in its formulation, including the existence of the principle of non-intervention which does not open opportunities for other nations or countries to intervene against human rights violations

${ }^{29}$ Petcharamesree, S. 2016. ASEAN human rights regime and mainstreaming the responsibility to protect: Challenges and prospects. Global Responsibility to Protect, 8(2-3), p. 133-157. 
committed in a state committed by Myanmar to the Rohingya ethnicity). Another deficiency is the absence of a universal or regional instrument that applies the concept of a balance between the fulfillment of rights and the guarantee of freedom of duty and responsibility for protecting human rights. By seeing conditions like this, ASEAN member countries must continue to approach Myanmar to immediately resolve the Rohingya case so as not to cause many victims.

\section{CONCLUSION}

The protection of ethnic groups and the right to citizenship has quite a number of arrangements in international law. But in practice there are still many violations that occur. One of the ways of AICHR's involvement in the Rohingya case is by holding meetings or forums. This was done as an effort to obtain information related to the development of the Rohingya case. In the case of Rohingya, AICHR was faced with several obstacles, namely obstacles that came from the AICHR institution itself. This includes the imbalance between the promotion and protection functions that AICHR has. This refers to the 14 mandates of AICHR regulated in the TOR, only two specific mandates show the implementation of the protection function, namely the mandate of gathering information related to the progress of the implementation of promotion and protection of human rights in each member country and the mandate to conduct thematic studies related to it. Human Rights in ASEAN. The two mandates are still considered lacking in efforts to address human rights violations in ASEAN.

In decision making, AICHR uses consensus principles which are the basis for achieving AICHR regional decisions. In other words, AICHR can only take a decision on a case if it has been unanimously determined by the AICHR commissioners and also the Foreign Ministers of ASEAN member countries. The involvement of the Foreign Ministers of ASEAN member countries in making this decision illustrates that AICHR is an extension of the ASEAN member countries. AICHR also seems not independent and neutral. Yet as a human rights commission it must be independent and neutral. The lack of independence of AICHR is also evidenced by the appointment of AICHR commissioners by each of its member countries.

The Rohingya ethnic is an example of an ethnic group whose citizenship is not recognized, so that their rights are often violated, even they often get persecution. Ethnic who do not have citizenship, they are among those who are obliged to get attention from UNHCR and other international organizations related to human rights. For some Rohingyas who have fled to other countries to avoid persecution, they can be classified as refugees. So they can be protected under international refugee law. Transit 
countries, destination countries and UNHCR play an important role in overcoming the flow of Rohingya refugees which can be considered quite a lot. The role taken must be based on humanitarian considerations of the suffering of Rohingya refugees and the protection of human rights. Legal protection for Rohingyas based on international law is generally regulated in international instruments such as the Universal Declaration of Human Rights, International Covenant on Civil and Political Rights 1966, International Covenant on Economic, Social and Cultural Rights, Genocide Convention, International Convention Against Torture, International Convention on the Elimination of All Forms of Racial Discrimination 1965, Convention on the Elimination of All Forms of Discrimination, Against Women, the Convention on the Rights of the Child, and the Convention on the Status of Refugees. Based on the explanation above, it can be concluded that any form of violence directed at the Rohingya ethnic group committed by the Myanmar Government cannot be justified, especially since it is still within the scope of the Southeast Asian region. the other ten ASEAN member countries and the formation of the ASEAN Human Rights Body are used as a repulsion to minimize human rights violations that occurred in Southeast Asia.

\section{BIBLIOGRAPHY}

\section{Books}

Baehr, Peter, Pieter Van Dijk, Adnan B. Nasution, Leo Zwaak, 2001, Instrumen Internasional Pokok Hak-hak Asasi Manusia, Yayasan Obor Indonesia, Jakarta.

Beitz, Charles, 2009, The Idea of Human Rights, Oxford University Press.

Blokker and Schemers, 2003, International Institutional Law, Fourth Edition, Leiden.

Eide (et.al.), Asbjorn, 1995, Economic, Social and Cultural Rights, A Textbook, Martinus Nijhoff, Dordrecht.

Ifdal Kasim \& Johanes da Masenus Arus (eds.), 2001, Hak Ekonomi, Sosial dan Budaya: Esai-esai Pilihan, Lembaga Studi dan Advokasi Masyarakat (Elsam), Jakarta.

Leider, J. (2018). Rohingya: The history of a Muslim identity in Myanmar. In Oxford Research Encyclopedia of Asian History.

Soerjono Soekanto dan Sri Mamudji, 2001, Penelitian Hukum Normatif, Raja Grafindo, Jakarta.

\section{Law and Regulation}

ASEAN Charter

Convention on the Elimination of All Forms of Discrimination Against Women

Genocide Convention

International Convention Against Torture

International Convention on the Elimination of All Forms of Racial Discrimination 
1965

International Covenant on Civil and Political Rights 1966

International Covenant on Economic, Social and Cultural Rights

the Convention on the Rights of the Child

the Convention on the Status of Refugees

Universal Declaration of Human Rights

\section{Journal/Mass Media / Papers / Dictionaries}

Arendshorst, J. (2009). The dilemma of non-interference: Myanmar, human rights, and the ASEAN charter. Nw. UJ Int'l Hum. Rts., 8.

Arianta, K., Mangku, D. G. S., \& Yuliartini, N. P. R. (2020). Perlindungan Hukum Bagi Kaum Etnis Rohingya Dalam Perspektif Hak Asasi Manusia Internasional.Jurnal Komunitas Yustisia, 1(1).

Bandoro, Bantarto, 2003, Mahatir's Myanmar Policy Not Just Empty Rhetoric, The Jakarta Post, tanggal 29 Juli 2003

Bandoro, Bantarto, 2006, Mynamar dan Negara-negara Ekstra Regional : Perspektif "Mesin Presto", Analisis CSIS Vol. 35 Nomor 2, Jakarta.

Beiter, Klaus Dieter, 2005, The Protection of the Right to Education by International Law, Martinus Nijhoff Publisher.

Beyrer, C., \& Kamarulzaman, A. (2017). Ethnic cleansing in Myanmar: the Rohingya crisis and human rights. The Lancet, 390(10102).

Brooten, L. (2015). Blind spots in human rights coverage: Framing violence against the Rohingya in Myanmar/Burma. Popular Communication, 13(2).

Desierto, D. A. (2010). ASEAN's Constitutionalization of International Law: Challenges to Evolution Under the New ASEAN Charter. Colum. J. Transnat'l L.

Haar, R. J., Wang, K., Venters, H., Salonen, S., Patel, R., Nelson, T., ... \& Parmar, P. K. (2019). Documentation of human rights abuses among Rohingya refugees from Myanmar. Conflict and health, 13(1).

Haque, M. M. (2017). Rohingya ethnic muslim minority and the 1982 citizenship law in burma. Journal of Muslim Minority Affairs, 37(4).

Kurniawan, N. (2018). Kasus Rohingya dan Tanggung Jawab Negara dalam Penegakan Hak Asasi Manusia. Jurnal Konstitusi, 14(4).

Lee, R. (2014). A politician, not an icon: Aung San Suu Kyi's silence on Myanmar's Muslim Rohingya. Islam and Christian-Muslim Relations, 25(3).

Mahmood, S. S., Wroe, E., Fuller, A., \& Leaning, J. (2017). The Rohingya people of Myanmar: health, human rights, and identity. The Lancet, 389(10081).

Mangku, D. G. S. (2011). Peluang dan tantangan ASEAN dalam penyelesaian sengketa Kuil Preah Vihear di perbatasan Kamboja dan Thailand. Pandecta: Jurnal Penelitian Ilmu Hukum (Research Law Journal), 6(2).

Petcharamesree, S. (2016). ASEAN human rights regime and mainstreaming the responsibility to protect: Challenges and prospects. Global Responsibility to 
Protect, 8(2-3).

Seah, D. (2009). The ASEAN Charter. The International and Comparative Law Quarterly, 58(1).

Shivakoti, R. (2017). ASEAN's role in the Rohingya refugee crisis. Forced Migration Review, 56 .

Singh, B. (2014). ASEAN, Myanmar and the Rohingya issue. Himalayan and Central Asian Studies, 18(1/2).

Wringe, Colin, 2006, Moral Education: Beyond the Teaching Rights and Wrong, Springer. 